\title{
Accounting
}

\section{The impact of sustainability development reporting on the environmental performance in Jordanian government}

\author{
Mohammad Jebreel $^{a^{*}}$, Jebreel Jebreel ${ }^{\mathrm{b}}$ and ABd ALSalam ALhamed
}

${ }^{a}$ Department of Accounting, Faculty of Business in Applied Science Private University, Amman, Jordan

${ }^{b}$ PhD Candidate, School of Maritime, Business and Management, University Malaysia Terengganu, Kuala Terengganu, Malaysia

${ }^{c}$ Finance department, Faculty of Business in Applied Science Private University, Amman, Jordan

\section{H R O N I C L E}

Article history:

Received March 72020

Received in revised format March

102020

Accepted May 12020

Available online

May 12020

Keywords:

Sustainability

Environmental disclosure

Environmental performance

\section{A B S T R A C T}

This research explores the significance of sustainability development through the role of environmental disclosure in Jordanian ministries and government departments by focusing on ministries and government departments that are related with the environment. This research presents the relationship between the environmental disclosure in annual reports and its impact on the overall environmental performance in Jordan, with the use of a mixed approach that will provide better quality of research results. The quantitative approach was used to examine the budgets of 22 ministries and government departments. The study was conducted using the time series from 2006 to 2015. The qualitative approach was conducted to raise the issues related to the subject that are not looked at in the quantitative study and to understand the perception of respondents in the ministries and government departments on the factors and items included in annual reports affecting of environmental disclosure and environmental performance in Jordanian governments. The results show a significant relationship between environmental disclosure and environmental performance in Jordanian government. The findings of this paper present new implications for theorists and practitioners of sustainability development by presenting the importance of the impact of environmental disclosure in the ministries and departments and its relationship on environmental performance of the Jordanian government.

\section{Introduction}

In light of the importance environmental and social issues in the world, there has been an increase in research on sustainability reports (Unerman et al., 2007). This has led to the interest and focus of international organizations and stakeholders in environmental disclosure issues from both the public and private sectors. Most studies in environmental information disclosure was in private sector while at the public sector was limited (Bloomqusit, 2006; Cho \& Patten, 2007; Aerts \& Cormier, 2009; Cho, 2009). Ball and Grubnic (2007) found that researches regarding the nature of environmental data in public sector was lacking even though the public sector is considered the basis of all sectors in a country. Government organizations strive to make public as much as possible regarding the information and activities related to the environmental aspects in their annual reports (Kolk 1999), recognizing that increasing public and stakeholder concerns about environmental pollution undermine stakeholder confidence and lose legitimacy and continuity (García-Sánchez et al., 2013). Social theory argues that social pressures and the threat of legitimacy by stakeholders and the public lead to weak environmental performance in organizations,

* Corresponding author

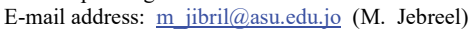


forcing organizations to enhance the role of environmental disclosure for a change on how their shareholders perceive their environmental performance (Clarkson et al., 2008). This also led to the increased demand for accurate and reliable information on the environmental indexes of the organizations in the government and private sectors (Buchholz \& Rosenthal, 2004). Environmental and annual reports serve to satisfy the need of the community and stakeholders to determine the environmental performance (Gray et al., 1995). The previous literature, the legitimacy theory was used to analyze the motives for disclosing environmental information in the private sector (Dowling \& Pfeffer, 1975; Lindblom, 1993; Deegan, 2007). Conversely, Lodhia (2010) mentioned that the higher expectations for performance by the society and stakeholders along with stricter regulations puts increased pressure on the public sector. Clarkson et al. (2008) found conflicting results when using social and political theories to analyze the relationship between environmental performance and disclosure within financial reports. Other studies have mentioned the increasing environmental information disclosure did not lead to an increase in environmental performance (Hughes et al., 2001; García-Sánchez et al., 2013), while some studies, (e.g. Milgrom, 1981; Deegan, 2007; Bewley \& Li, 2000) found voluntary disclosure lead to increased environmental performance with increasing environmental information disclosure. García-Sánchez et al. (2013) indicated that the voluntary disclosure theory is the most applicable. Lodhia (2010) and Dumay et al. (2011) suggested that due to the existence of both voluntary and mandatory pressures on the public sector to disclose sustainability and environmental information in the financial reports in the public sector, there is a need to expand the theories regarding disclosure of sustainability. Finally, the study uses interpretations of voluntary disclosure theories and institutional theory as a basis for the public-sector sustainability perspective. In addition, this research also presents new perceptions about the impacts of reporting on environmental disclosures and the relationship between the level of disclosure of environmental in the ministries and government units and the level of Jordanian environmental performance.

\section{Prior Literature}

Disclosure of information is one of the important tools used by institutions and departments in the public or private sector to justify their actions. The importance of disclosing information around the world has increased after revelations of scandals resulting from the lack of information disclosure by companies and institutions. Owusu-Ansah (1998) and Ağca and Onder (2007) defined information disclosure as informing the public about data relating to the financial position and performance of the companies or institutions. Clearly, available literature that seeks to reveal sustainability in public-sector versus private sector reports is weak. This paper attempts to fill gap in the shortage of studies of sustainability development reports in the public sector by explaining the impact of environmental disclosure strategies and environmental performance in the public sector in Jordan. Burritt and Welch (1997) explored an approach to develop the Australian public sector environmental accountability framework and noted that the main objective of accountability was to understand the stakeholders of ecosystems, identify changes in the environmental performance of the government sector and link them with environmental accountability. Moreover, Rahman et al. (2004) reported that the Volta River are using financial reports for environment Authority of the Ghanaian government was a result of external support from the international Bank rather than a way to support environmental performance. Through a survey of public sector reports, Dickinson et al. (2005) found that performance was the main driver of sustainability reporting in national, regional and local governments, mostly due to internal considerations. Frost and Seamer (2002) found that the supported and development of environmental management practices and the level of environmental disclosure were highly correlated and indicated a positive effect between management structures and environmental disclosure of government sector entities in New South Wales and found that this disclosure was the result of fear of the demise of legitimacy. Oates and Motlagh (2016) developed analysis indexes for financial reports and showed that there was a positive relationship between environmental disclosure and basic environmental performance and also noted a significant weakness in the nature of environmental disclosure among Victorian public organizations, with an average of 13.72 out of 100 . Furthermore, Clarkson et al. (2008) reported a positive relationship between environmental disclosure and performance. Furthermore, Sutantoputra et al. (2012) found that the level of environmental disclosure in the annual reports was low and the level of disclosure was assessed using content analysis which was developed through the Global Reporting Initiative GRI. Also, mentioned that not have strong relationship between environmental performance and the level of environmental disclosure. Conflicting information was shown in literature about the linkage between environmental information disclosure and environmental performance. A study carried out on 131 US companies by looking at their annual reports resulted in a negative relationship between environmental performance and disclosure. In addition, it was found that by measuring environmental performance through emissions normalized with sales, companies with weak environmental performance actually disclosed more data compared to those with better environmental performance. Furthermore Ingram and Frazier (1980) and Freedman and Wasley (1990) did not find any relationship between environmental disclosure and performance. Based on the view of the above literature, an ambiguous link exists between environmental performance and level of disclosure in the public sector 's annual reports. Therefore, this study going to test this hypothesis:

$\mathrm{H}_{1}$ : There is a significant relationship between disclosure of government environmental information and environmental performance. 
In general, the ministries and government departments seek to disclose environmental information through annual reports to cover all environmental issues. This information can be found throughout the annual reports of ministries and departments that have a direct or indirect relationship with the environment. Therefore, this study collected data and information from the annual reports of ministries and government departments selected to monitor the information disclosed. Therefore, the period 20062015 was chosen due to the issuance of the general environment law by the government of Jordan, through which the ministry of environment was established. This research used content analysis to examine the financial reports of 2006-2015 as explained by the most previous research in this area (Guthrie \& Abeysekara, 2006; Owen, 2008). In addition, this study used quantitative and qualitative methods to analyze data to compensate for literature weaknesses and strengths. The mixed methods also help to understand complex data and provide a more complete analysis for research (Creswell, 2003; Bryman, 2006). Quantitative data were composed, analyzed and compared to evaluate the importance of the level of disclosure of environmental information and its relationship to environmental performance in the ministries and government units. Additionally, this paper used the disclosure index included in the GRI guidelines (Global Reporting Initiative). This index has 60 items grouped into 11 categories: general environmental considerations and strategies, ministry and the department's commitment to the community, targets and achievements, financial data, stakeholder engagement and other initiatives, sustainability, compliance/non-compliance, aspect environmental, research and development, environmental performance indicators and environmental performance data. As for the qualitative approach, semi-structured interviews were carried out in this study on managers or consultants in ministries and government departments in Jordan. For the purpose of this study, it was found that the face-to-face method is more useful compared to other methods. This method contains a list of questions processed for discussion to illustrate many issues. The content is then analyzed in this approach by analyzing each individual case (Yin, 2003; Kohlbacher, 2006).

\subsection{Samples}

The sample used in this study has to do with the ministries and the government departments which are related with the environment in Jordan. There are 22 relevant ministries and government departments in Jordan which represents about 18 per cent of the ministries and the government departments in Jordan. All data was collected from 10 ministries and 12 departments of the Jordanian government. Their annual reports for 2006 to 2015 were analyzed. Year 2006 was selected for the starting year due to the Environmental Protection Law that was issued along with the establishment of the Ministry of Environment. Furthermore, in 2006 Jordan issued a national plan for environmental protection. Qualitative data was collected during interviews the managers in the government departments and ministries in Jordan. The most researchers interested the explanatory research design due to investigates and measures the relationship between variables and the effect on existing assumptions that a specific change will have (Creswell, 2003; Clor-Proell \& Maines, 2014; Heckman \& Pinto,2015). This means that the disclosed information available in the annual reports for these ministries and government departments are valid and reliable. This research adopted the quantitative method to measure correlation between the level of environmental information disclosure and environmental performance using EViews 7. Based on the analysis of panel data method for this study, the regression equation is as follows:

$$
\begin{aligned}
& E P=\beta_{0}+\beta_{1} A I R_{i t 1}+\beta_{2} D E A T H S_{i t 2}+\beta_{3} \text { WASTE }_{i t 3}+\beta_{4} A G R I C U l_{i t 4}+\beta_{5} W A T E R_{i t 5}+\beta_{6} E N E R G Y_{i t 6}+\beta_{7} \text { BIOD }_{i t 7} \\
& +\beta_{8} D I_{i t 8}+\varepsilon
\end{aligned}
$$

where;

EP

AIR

DEATHS

WASTE

AGRICUL

WATER

ENERGY

BIOD

DI

$\varepsilon$
$=$ Environmental Performance

$=$ Annual air quality growth rate

$=$ Child mortality growth rate

$=$ growth rate of wastewater treatment

$=$ Growth rate of agricultural contribution in GDP

$=$ Growth rate of available water quantities per year

$=$ Annual renewable energy growth rate

$=$ growth rate of annual cultivated area of total land

$=$ disclosure Level for environmental information

$=$ Error Term. 
In this research, the environmental performance (EP) was used as dependent variable, which represented by many performance indicator (e.g. EP, AIR, DEATHS, WASTE, AGRICUL, WATER ENERGY, BIOD) while the independent variable was the level of disclosure for environmental information (DI). Previous researchers used the disclosure of environmental information in their studies to justify their results (Clarkson et al., 2008; Oates \& Motlagh, 2016; Clor-Proell \& Maines, 2014). Because of the understanding of the relevance between environmental disclosure and environmental performance, this also improves the level of sustainability developments in the public sector among government organizations.

\section{Results and Discussion}

The finding of this study showed that 40 observations for the 10 years between (2006-2015) for the 22 ministries and government departments in Jordan as explained in Table 1. The mean of the dependent variable, environmental all performance (EP), was 0.320 which is represented by air quality, death rate, treated water, agriculture GDP, water value, energy rate and biodiversity performance $(-0.069,-0.106,0.430,0.111,-0.05$ and 0.337 respectively). Moreover, the mean of the disclosure of environmental information was 0.649. For this study, the standard deviation of environmental performance was 0.105 with the standard deviation for air quality, death rate, treated water, agriculture GDP, water value, energy rate and biodiversity performance being $0.046,0.134,0.220,0.143,0.136,0.229$ and 0.097 respectively. While, the disclosure of environment information has a deviation of 0.045 .

\section{Table 1}

The results of descriptive analysis.

\begin{tabular}{|c|c|c|c|c|c|}
\hline Variable & Mean & Median & Std.Deviation & Minimum & Maximum \\
\hline Airquality & -0.069 & -0.065 & 0.046 & -0.140 & 0.000 \\
\hline Deaths & -0.106 & -0.060 & 0.134 & -0.35 & 0.000 \\
\hline Treatedwater & 0.430 & 0.420 & 0.220 & 0.000 & 0.830 \\
\hline Agriculturgdp & 0.111 & 0.100 & 0.143 & -0.080 & 0.420 \\
\hline Watervaiuable & -0.05 & -0.075 & 0.136 & -0.240 & 0.250 \\
\hline Energyrate & 0.337 & 0.330 & 0.229 & 0.000 & 0.820 \\
\hline Biodversityperformance & -0.320 & -0.015 & 0.097 & -0.260 & 0.090 \\
\hline Allperformance & 0.089 & 0.065 & 0.105 & -0.040 & 0.320 \\
\hline Disclosure & 0.649 & 0.647 & 0.045 & 0.600 & 0.720 \\
\hline
\end{tabular}

\subsection{The relationship between disclosure Level for environmental information and environmental performance}

The goal of this research is to determine the relationship between the level of environmental information disclosure and environmental performance. The findings are presented in Table 2. The finding explained that the level of disclosure of environmental information and environmental performance have a significant relationship $(\mathrm{B}=2.11, \mathrm{~T}=13.8, \mathrm{P}=0.000)$. Hence, the hypothesis is accepted. This indicates that, the level of disclosure of environment information would help enhance environmental performance in the ministries and the government departments in Jordan.

\section{Table 2}

The result between disclosure and environment performance

\begin{tabular}{|c|c|c|c|c|c|}
\hline & Hypothesis & Coefficient & t-Statistic & Prob. & Remark \\
\hline H1: Disclosure & $\rightarrow$ Environment Performance & 2.111651 & 13.86912 & 0.000 & supported \\
\hline
\end{tabular}

\section{Conclusions}

The results of this research proved that, the use of the level of disclosure of environment information in the ministries and the government departments in Jordan is significantly related to environmental performance. Environmental disclosure enables the government to disclose environmental information to reflect its actual environmental performance by understanding the driving factors for detection. In addition, the disclosure index is rising every year and also confirmed by Horsley (2009). This indicates that the public interest in environmental information disclosure and involvements in environmental decision-making continues to increase. The results of this study in this regard is consistent with prior researchers (such as Verrecchia, 1983; Dye, 1985; AlTuwaijri et al, 2004; Oates \& Motlagh, 2016). This implies that, the government organizations are hiding something when they fail to make full disclosures. Furthermore, they explained the actual disclosures are reliable due to the probability of lawsuits and other legal problems. Based on the respondent's answers across financial managers in the ministries and government departments in Jordan it was demonstrated that the level of disclosure of environment information has a direct influence on environmental performance. The weakness in environmental performance in Jordan due to the low of the significant of the 
disclosure for environmental information as result as no have attention about that from Jordanian studies (Oates \& Motlagh, 2016). In addition, Tariq et al. (2017) indicated that awareness among stakeholders and that the government's regulations on social and environmental characteristics remain weak in Jordan. The findings of this research validate the theoretical views of the institution, legitimacy and voluntary theories by empirically revealing the involvement of supporting the role of the level of disclosure of environmental information in government organizations, which is expected to improve environmental performance. Finally, the practical implication of this research is that, the paper provides an insight into the effect of the new environment and improve their environmental expenditures and disclosure through training programs for practitioners, and especially managers, whereas, this is considered vital to enhance to understand the significance of the environmental information for decision-making. Hence, we need to support the role of sustainability development as a strategic management tool in enhancing the environmental performance in the ministries and government departments in Jordan.

\section{Acknowledgements}

The corresponding author is grateful to the Applied Science Private University for the partial financial support granted to this research project.

\section{References}

Aerts, W., \& Cormier, D. (2009). Media legitimacy and corporate environmental communication. Accounting, Organizations and Society, 34(1), 1-27.

Ağca, A., \& Önder, Ş. (2007). Voluntary disclosure in Turkey: A study on firms listed in Istanbul Stock Exchange (ISE). Problems and Perspectives in Management, 5(3), 241-286.

Al-Tuwaijri, S. A., Christensen, T. E., \& Hughes Ii, K. E. (2004). The relations among environmental disclosure, environmental performance, and economic performance: a simultaneous equations approach. Accounting, Organizations and Society, 29(56), 447-471.

Unerman, J., Bebbington, J., \& O’Dwyer, B. (2007). Introduction to sustainability accounting and accountability. Sustainability Accounting and Accountability, 1-16.

Bewley, K., \& Li, Y. (2000). Disclosure of environmental information by Canadian manufacturing companies: a voluntary disclosure perspective. In Advances in Environmental Accounting \& Management (pp. 201-226). Emerald Group Publishing Limited.

Bryman, A. (2006). Integrating quantitative and qualitative research: how is it done?. Qualitative research, 6(1), 97-113.

Buchholz, R. A., \& Rosenthal, S. B. (2004). Stakeholder theory and public policy: How governments matter. Journal of Business Ethics, 51(2), 143-153.

Burritt, R. L., \& Welch, S. (1997). Accountability for environmental performance of the Australian Commonwealth public sector. Accounting, Auditing \& Accountability Journal, 10(4), 532-561.

Cho, C. H. (2009). Legitimation strategies used in response to environmental disaster: A French case study of Total S. A.'s Erika and AZF incidents. European Accounting Review, 18(1), 33-62

Cho, C., \& Patten, D.M. (2007) The role of environmental disclosure as legitimacy tools: A research note. Accounting Organizations and Society, 32(7), 639-647

Clarkson, P. M., Li, Y., Richardson, G. D., \& Vasvari, F. P. (2008). Revisiting the relation between environmental performance and environmental disclosure: An empirical analysis. Accounting, organizations and society, 33(4-5), 303-327.

Clor-Proell, S. M., \& Maines, L. A. (2014). The impact of recognition versus disclosure on financial information: A preparer's perspective. Journal of Accounting Research, 52(3), 671-701.

Creswell, J. W., Plano Clark, V. L., Gutmann, M. L., \& Hanson, W. E. (2003). Advanced mixed methods research designs. Handbook of mixed methods in social and behavioral research, 209, 240.

Deegan, C. (2007). Organizational legitimacy as a motive for sustainability reporting.in Unerman, J, Bebbington, J and O’Dwyer, B (eds) Sustainability Accounting and Accountability(pp.) Routledge, London.

Deegan, C., \& Bloomquist, C. (2006). Stakeholder influence on corporate reporting: An exploration of the interaction between WWF-Australia and the Australian minerals industry. Accounting, Organizations and Society, 31(4), $343-372$.

Dickinson, J., Leeson, R., Ivers, J., Karic, J. (2005) Sustainability Reporting by Public Agencies: International Uptake, Forms and Practice, The Centre for Public Agency Sustainability Reporting, Melbourne.

Dowling, J., \& Pfeffer, J. (1975). Organizational legitimacy: Social values and organizational behavior. Pacific sociological review, $18(1), 122-136$.

Dumay, J., Guthrie, J., \&Farneti, F. (2010). GRI sustainability reporting guidelines for public and third sector organizations: A critical review. Public Management Review, 12(4), 531-548

Dye, R. A. (1985). Disclosure of non-proprietary information. Journal of Accounting Research, 23(1), 123-145, Spring.

Freedman, M., \& Wasley, C. (1990). The association between environmental performance and environmental disclosure in annual reports and 10Ks. Advances in Public Interest Accounting, 3(2), 183-193. 
Frost, G. R., \& Seamer, M. (2002). Adoption of environmental reporting and management practices: an analysis of New South Wales public sector entities. Financial Accountability \& Management, 18(2), 103-127.

García-Sánchez, I. M., Frías-Aceituno, J. V., \& Rodríguez-Domínguez, L. (2013). Determinants of corporate social disclosure in Spanish local governments. Journal of Cleaner Production, 39, 60-72.

Gray, R., Kouhy, R., and Lavers, S. 1995a. Methodological themes constructing a research database of social and environmental reporting by UK companies. Accounting, Auditing and Accountability Journal, 8(2): 78-101

Guthrie, J., \& Abeysekera, I. (2006). Content Analysis of Social, Environmental Reporting: What is New?. Journal of Human Resource Costing \& Accounting, 10, 2: $114-26$.

Heckman, J., \& Pinto, R. (2015). Causal analysis after Haavelmo. Econometric Theory, 31(1), 115-151.

Horsley, J. P. (2009). Public participation in the people's republic: developing a more participatory governance model in China. Retrieved July, 30, 2010.

Hughes, S. B., Anderson, A., \& Golden, S. (2001). Corporate environmental disclosures: are they useful in determining environmental performance?. Journal of Accounting and Public Policy, 20(3), 217-240.

Ingram, R. \& Frazier, K. (1980). Environmental performance and corporate disclosure. Journal of Accounting Research, 18, 612-622.

Kohlbacher, F. (2006). The use of qualitative content analysis in case study research. Forum: Qualitative Social Research, 7(1).

Kolk, A., Van Tulder, R., \& Welters, C. (1999). International codes of conduct and corporate social responsibility: can transnational corporations regulate themselves?. Transnational Corporations, 8(1), 143-180.

Lindblom, C.K. (1993). The implications of organizational legitimacy for corporate social performance and disclosure. Paper presented at the Critical Perspectives on Accounting Conference. New York, US.

Lodhia, S. K. (2010). Sustainability reporting by the Australian commonwealth public sector: an application of new institutional theory. In Proceedings of the 9th Australasian conference on social and environment accounting research (CSEAR) (pp. 57).

Milgrom, P. R. (1981). Good news and bad news: Representation theorems and applications. The Bell Journal of Economics, 12(2), 380-391.

Oates, G., \& Moradi-Motlagh, A. (2016). Is voluntary disclosure of environmental performance associated with actual environmental performance? Evidence from Victorian local governments, Australia. Australasian Journal of Environmental Management, 23(2), 194-205.

Owen, D. (2008). Chronicles of wasted time?: A personal reflection on the current state of, and future prospects for, social and environmental accounting research. Accounting, Auditing \& Accountability Journal, 21(2), 240-267.

Owusu-Ansah, S. (1998). The impact of corporate attributes on the extent of mandatory disclosure and reporting by listed companies in Zimbabwe. The International Journal of Accounting, 33(5), 605-631.

Patten, D. M. (2002). The relation between environmental performance and environmental disclosure: a research note. Accounting, organizations and Society, 27(8), 763-773.

Rahaman, A. S., Lawrence, S., \& Roper, J. (2004). Social and environmental reporting at the VRA: institutionalized legitimacy or legitimation crisis? Critical Perspectives on Accounting, 15(1), 35-56.

Sutantoputra, A. W., Lindorff, M., \& Johnson, E. P. (2012). The relationship between environmental performance and environmental disclosure. Australasian Journal of Environmental Management, 19(1), 51-65.

Unerman, J. (2007). Stakeholder engagement and dialogue. IN Unerman, J., Bebbington, J. \&O'dwyer, B.(Eds.) Sustainability, Accounting and Accountability.

Verrecchia, R. (1983). Discretionary disclosure. Journal of Accounting and Economics, 5, $179-194$.

Yin, R. K. (2003). Case study research design and methods third edition. Applied social research methods series, 5.

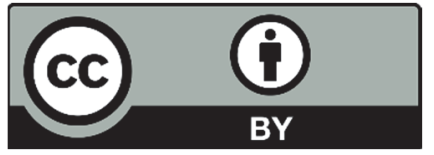

(C) 2020 by the authors; licensee Growing Science, Canada. This is an open access article distributed under the terms and conditions of the Creative Commons Attribution (CC-BY) license (http://creativecommons.org/licenses/by/4.0/). 